\title{
Letter
}

\section{Democracy in Nigeria: the challenge of infectious disease control}

\author{
Ike Anya, ${ }^{1}$ Chikwe Ihekweazu. ${ }^{2}$ \\ ${ }^{1}$ Health Protection Agency South West, The Wheelhouse, Bond's Mill, Stonehouse, Gloucester GL10 3RF, UK. \\ ${ }^{2}$ Health Protection Agency, Centre for Infections, 61 Colindale Avenue, London, NW9 5EQ, UK.
}

J Infect Developing Countries 2008; 2(2):151-153.

Received 18 January 2008 - Accepted 20 February 2008.

Copyright @ 2008 Anya \& Ihekweazu. This is an open access article distributed under the Creative Commons Attribution License, which permits unrestricted use, distribution, and reproduction in any medium, provided the original work is properly cited.

The relationship between democracy and health outcomes has been the focus of recent research interest [1,2]. With an estimated 140 million people, Nigeria is the most populous country in Africa. In May 2007, it marked eight years of unbroken civilian government, the longest period of civilian rule in its post-independence history with the noticeably peaceful handover of power from President Obasanjo to President Yar'adua. These eight years of relative peace and democratic governance in Nigeria have seen changes in the economy with steady growth, a large reduction in external debt, and structural reforms of the financial and telecommunications sectors. These changes, however, have had little impact on the lives of ordinary Nigerians [3]. In the health sector, progress has been slow and many challenges remain: from weak health systems to tackling HIV/AIDS; from improving immunization coverage (which in the past has impeded the global goal of eradicating polio) to implementing the new International Health Regulations (IHR); from achieving the Millennium Developmental Goals (MDGs) to preparing for pandemic flu. We examine the progress made and challenges faced from an infectious diseases perspective in Nigeria over the past eight years.

In northern Nigeria in 2003, concerns about vaccine safety, i.e. rumours that the polio vaccine caused sterility, led to a halt in polio immunization. This led to the resurgence of the disease in Nigeria, and the re-infection of several neighbouring countries, setting back the entire global eradication programme [4]. While the last two years have witnessed a renewed response with reinvigorated vaccination campaigns, the disease has persisted and Nigeria remains one of four countries in which the circulation of the wild poliovirus has never been interrupted, recording the highest number of confirmed polio cases in 2006 and 2007 [5]. Routine immunisations for other vaccine preventable diseases remain below $50 \%$ (most recent data 2005) [6]. Outbreaks of measles, for which a cheap, safe and easily administered vaccine has been available for two decades, continue to occur with unacceptable mortality rates [7].

In February 2006, the first case of highly pathogenic H5N1 avian influenza in domestic birds in Africa was reported from a poultry farm in Nigeria [8]. The case took 5 weeks to be confirmed. Health officials were quickly overwhelmed by the challenge of culling thousands of chickens, responding too late and with too little as the disease spread. Each week brought new anxiety and weird responses [9]. The response to this outbreak provided a troubling illustration of what can happen when $\mathrm{H} 5 \mathrm{~N} 1$ hits a developing country with a weak health care system and limited capacity in infectious disease control.

Nigeria has the third largest number of people living with HIV in the world [10]. In 1999 the new civilian government set up a National Action Committee on AIDS (NACA) charged with coordinating various activities related to the prevention and control of HIV/AIDS in the country. The committee has recently been transformed by legislative act into a statutory agency. The prevalence rate based on national sentinel surveys rose from 1.8 per cent in 1991 to $5.8 \%$ in 2001 but in 2006 it was estimated at 3.9 per cent [11]. However, marked variation within the country 
persists with prevalence rates as high as 12 per cent in some states [12]. In 2005, the Nigerian government committed to universal provision of free antiretroviral therapy, the implementation of which has been largely funded by the Global Fund, PEPFAR [12] and the World Bank. While some progress has been made, with an estimated 92,000 people currently on treatment [12], poor management, shoddy coordination, and capacity issues have impeded further progress in this area.

In Nigeria, there is no broad technical agency with the capacity for the surveillance and response to infectious disease. This responsibility lies with technocrats in the Ministry of Health. Most surveillance and response activities are managed via disease specific vertical programmes, with little coordination between them, leading to inefficient use of scarce human resources. The recent announcement that a National Disease Control and Prevention Centre (NDCPC) is to be created out of the current Central Public Health Laboratory in Lagos [13] is a welcome development but the challenge will lie in its implementation.

Nigeria must face up to the challenge of building the capacity to rapidly respond and manage infectious disease threats. The availability of several international funding sources and advances in technology have made infectious disease control activities significantly easier in recent times. However, accessing and optimizing the use of these resources requires bold, visionary and strategic leadership. The most recent Minister of Health ordered a rapid review of the health system and requested legislative review of how past donor funds have been expended [14]. The case for investing in health, not just as an altruistic service to a population but to promote economic development, has been elucidated by the World Health Organization's report on Macroeconomics and Health [15]. Nigeria, with its huge population, cannot afford to neglect the health of its people as it seeks economic development in a stable democratic environment.

\section{References}

1. Franco A, Alvarez-Dardet C, Ruiz MT (2004) Effect of democracy on health: ecological study. BMJ 329:14213.

2. Ruger JP (2005) Democracy and health. QJM 98(4):299304.

3. Okonjo-Iweala N and Osafo-Kwaako P (2007) Nigeria's Economic Reforms Progress and Challenges in Brookings Institution Working Paper. Available: http://www3.brookings.edu/views/papers/20070323okonjo iweala.pdf Accessed October 12007.

4. Centers for Disease Control and Prevention (2005) Progress toward poliomyelitis eradication. Morb Mortal Wkly Rep. 54(4):97-9. Available: http://www.cdc.gov/mmwR/preview/mmwrhtml/mm5404a 4.htm accessed 01/10/07.

5. Centers for Disease Control and Prevention (2007) Progress Toward Interruption of Wild Poliovirus Transmission Worldwide, January 2006--May 2007. Available:

http://www.cdc.gov/mmwr/preview/mmwrhtml/mm5627a3. htm accessed 01/10/07.

6. UNICEF. At a glance: Nigeria. Available: http://www.unicef.org/infobycountry/nigeria_statistics.html accessed 10/02/08.

7. Grais RF et al. (2007) Unacceptably high mortality related to measles epidemics in Niger, Nigeria, and Chad. PLoS Med. 2007 Jan;4(1):e16. Available http://medicine. plosjournals.org/perlserv/?request=getdocument\&doi=10.1371\%2Fjournal.pmed.0040016\&ct=1 accessed 18/01/08.

8. World Health Organisation (2006) Avian influenza situation (birds) in Nigeria. Available: http://www.who.int/csr/don/2006_02_08/en/ accessed 18/01/08.

9. Ihekweazu C (2007) The Blind Leading the Blind: How the Nigerian Press Reported the First Cases of Avian Influenza in Africa in International Meeting on Emerging Diseases and Surveillance, Austria. Abstract 8.021.

10. UNAIDS (2006) Report on the global AIDS epidemic. Available:

http://data.unaids.org/pub/GlobalReport/2006/2006_GR_ ANN2_en.pdf accessed October 12007.

11. UNAIDS (2006) Report on the global AIDS epidemic. Available:

http://data.unaids.org/pub/GlobalReport/2006/2006_GR_ ANN1M-Q_en.pdf accessed October 12007.

12. President's Emergency Plan for AIDS Relief (2007) Country Profile Nigeria. Available http://www.pepfar.gov/pepfar/press/81548.htm accessed October 12007.

13. Daily Triumph (2007) Minister inaugurates task force on medical laboratory policy. Available: http://www.triumphnewspapers.com/minister1192007.htm I accessed 01/10/07.

14. Daily Champion (2007) Nigeria: Minister Wants Health Ministry Probed. Available http://allafrica.com/stories/200709120564.html accessed October 12007.

15. World Health Organisation (2001). Macroeconomics and Health: Investing in Health for Economic Development; Report of the Commission on Macroeconomics and Health Chaired by Jeffrey D. Sachs. http://whqlibdoc.who.int/publications/2001/924154550X.p df accessed 01/10/07. 
Corresponding Author: Chikwe Ihekweazu, Health Protection Agency, Centre for Infections, 61 Colindale Avenue, London, NW9 5EQ, United Kingdom. Email: chikwe.ihekweazu@gmail.com

Conflict of interest: No conflict of interest is declared. 